\title{
Seasonal Occurrence of the Sesame Capsule Borer, Antigastra catalaunalis (Duponchel) and Parasitism Rate of the Ecto-larval Parasitoid Bracon hebetor Say in Sesame Plants at Ismailia
}

\author{
Nesrin A. El-Basha \\ Department of Biological Control, Plant Protection Research Institute, Agricultural Research Center, Giza, Egypt
}

Received: $1 / 3 / 2016$

\begin{abstract}
Field studies were conducted on the seasonal incidence of sesame capsule borer, Antigastra catalaunalis (Duponchel) (Lepidoptera: Pyralidae) and parasitism rate of its ecto-larval parasitoid Bracon hebetor Say (Hymenoptera: Braconidae) in two successive seasons of 2012 and 2013 at Ismailia Governorate. Results indicated that A. catalaunalis larvae appeared in mid-June (15 day after sowing) then increased gradually till the end of crop maturation $\left(2^{\text {nd }}\right.$ or $3^{\text {rd }}$ week of September). The highest percentage of infested branches, leaves, flowers and capsules was $75,72.5,62.5$ and $47.5 \%$ respectively in the first season and $70,70,55$ and $45 \%$, respectively in the second season. The incidence of $A$. catalaunalis larvae was higher in leaves or shoots than in flowers or capsules. Ambient temperature had a positive and significant correlation with percentage of infestation by A. catalaunalis as well as number of larvae per infested branches and flowers in the first season while it had non- significant negative correlation in the second season. The mean relative humidity percentages showed non- significant negative relationship with percentages of infestation or pest incidence during the two seasons. Rate of parasitism by $B$. hebetor varied among plant parts in which A. catalaunalis larvae were fed on during the two seasons; being higher in the second season. Maximum parasitism percentages were $28.3,32.5,26.3$ and $20 \%$ in infested branches, leaves, flowers and capsules in the first season and increased to $38.7,41.7,35.8$ and $21 \%$, respectively in the second one.
\end{abstract}

Keywords: Antigastra catalaunalis; seasonal occurrence; infestation parasitism rate; Bracon hebetor.

\section{INTRODUCTION}

Sesame (Sesamum indicum L.) is an old and important oil seed crop; being cultivated in Egypt, tropical and subtropical regions of the world (Seegeler, 1983; Iwo et al., 2002). It is considered to have both nutritional and medicinal values. Sesame leaf-roller or capsule borer Antigastra catalaunalis (Duponchel) (Lepidoptera: Pyralidae) is considered a key pest of sesame in Egypt (Abbas et al., 1989; Ahmed, 2007). It is very devastating pest of sesame crop and damages all plant parts; i.e., shoots, leaves, flowers and capsules by its devastating larval stage. Young larvae are less frequent on pods than on other plant parts. Older larvae infest the sesame capsules making an entrance hole on the lateral side and feed on the seeds inside the capsule leaving excreta on the seeds (Singh, 1983; Suliman et al., 2004; Narayanan and Nadarajan, 2005; Ahirwar et al., 2010). A. catalaunalis was the potential constraint to sesame production from seedling to maturity stage (Chaudhry et al., 1987; Selvanarayanan and Baskaran, 1996). In India, it recorded 10-71\% plant infestation and $10-43.5 \%$ capsule infestation, resulting in $8.9-71.5 \%$ yield loss and $66.31 \%$ seed loss per capsule (Kumar and Goel, 1994a). The percentage of seed damage in infested pods was $73.4 \%$ and the percentage of weight loss in damaged seeds was $100 \%$ (Kapadia, 1996). Antirrhinum majus and Duranta sp. act as alternate host plants of A. catalaunalis (Abbas et al., 1989)

To control A. catalaunalis, farmers use chemical insecticides, which could be toxic to natural enemies, thus disturbing the biological balance in the field and contaminating the environment. Bracon hebetor Say (Hymenoptera: Braconidae) is a polyphagous gregarious ecto-parasitoid of scores of pyralid species. B. hebetor has been used in many biological control programs in different parts of the world (Fagundes et al., 2005; Desai et al., 2007; Kyoung et al., 2008). It parasitizes several important lepidopterous pests of stored products and field crops (Gupta and Sharma, 2004; Shojaei et al., 2006). B. hebetor was the dominant associated parasitoid with $A$. catalaunalis in India (Jakhmola, 1983). In an earlier study, the reproductive biology of $B$. hebetor was studied on the larvae of A. catalaunalis (ElBasha, 2015)

To manage this pest efficiently, the understanding of the relationship between pest incidences, parasitoids that attack larvae and weather factors are very essential. This will be very helpful to avoid the peak activity of pest population and damage the crop by using the parasitoids.

The main objective of this study is to address the infestation rate by sesame capsule borer Antigastra catalaunalis, its seasonal incidence and total larval population in infested branches, leaves, flowers and capsules plants in two successive seasons of 2012 and 2013. Most importantly, rates of parasitism by the ectoparasitoid Bracon hebetor on A. catalaunalis larvae were also recorded in different plant parts in the two study seasons.

\section{MATERIALS AND METHODS}

\section{Sampling Method}

This study was conducted at the Experimental Farm, Ismailia Agricultural Research Station, Egypt, during the two sesame growing seasons of 2012 and 2013. Seeds of sesame cultivar (Shandawil 3) were sown in the last week of May 2012 and 2013 by Oil Crop Research Department, Ismailia Agricultural Research Station. This experiment was performed as complete Randomized Block Design (CRBD). Each 
experimental plot was $5 \times 4 \mathrm{~m}$ and replicated four times. No pesticide was applied in the selected field plots during the investigation periods. Sampling was taken from five randomly selected plants within each plot (Kumar et al., 2012).

The incidence of $A$. catalaunalis larvae/sesame tender shoot was recorded in terms of percentage of infested plants and number of larvae per 20 branches. Twenty terminals randomly branches of $20 \mathrm{~cm}$. (five branches/ plot) were taken at weekly intervals commencing 15 day after sowing from vegetative stage of the crop.

The incidence of sesame leaves, flowers (or flower buds) and capsules were recorded in terms of percentage of infested plants and number of larvae per 40 leaves, flowers or (flower buds) and capsules. Five sampling plants were chosen randomly in each plot. In each sampling plant, two leaves, flowers (or flower buds) and capsules were collected and inspected for calculation of infestation by $A$. catalaunalis larvae. The percentage of incidence was calculated by using the formula:

\section{Infestation $(\%)=$ No of infested plants $(\mathrm{B} / \mathrm{L} / \mathrm{F} / \mathrm{C}) \times 100$ Total no. of plants observed}

Where: $\mathrm{B}=$ Branch , $\mathrm{F}=$ Flower, $\mathrm{L}=$ leaf, $\mathrm{C}=$ capsule

The collected samples were placed in paper bags and transferred to the laboratory for further inspection with stereoscopic-microscope. Flower buds/flowers and pods of sesame were dissected and total larval population of A. catalaunalis was counted and percentage of infested sesame plants were estimated during the two successive years.

Percentages of parasitism and seasonal activity of the parasitoid $B$. hebetor in the same samples were investigated for the presence of parasitized larvae of $A$. catalaunalis by $B$. hebetor' immature stages. Parasitized larvae were kept individually in Petri dishes $(9 \mathrm{~cm})$ until cocoon formation. Number of total formed parasitoid cocoons (appeared in the Lab and those formed at the date of inspection) as well as rate of emergence of adult parasitoids were recorded as parasitoid success. The rate of parasitism was calculated according to the formula:

Parasitism $(\%)=\frac{\text { No. of parasitized host larvae }}{\text { No. of collected larvae }} \times 100$

Where: Collected larvae $=$ Total no. of parasitized and non-parasitized host larvae

\section{Statistical analysis}

Meteorological data, weekly means of air temperature $\left({ }^{\circ} \mathrm{C}\right)$ and relative humidity $(\% \mathrm{R} . \mathrm{H})$ were obtained during sesame growing seasons of 2012 and 2013. Simple correlations were worked out between incidence of $A$. catalaunalis in terms of percentage of infested plants or total larval population with the weather factors (Temp. ${ }^{\circ} \mathrm{C}$ and R.H.\%). Also, correlations were worked out between rates of parasitism by $B$. hebetor and the weather factors or total population of $A$. catalaunalis. Data obtained in all presented experiments were subjected to analysis of correlation coefficient using CoStat 6311 Windows Computer Program.

\section{RESULTS}

\section{Seasonal abundance of $A$. catalaunalis}

\subsection{Seasonal incidence of $A$. catalaunalis larvae in tender shoots}

Infestation rate relatively varied in the two seasons; being higher in the first one. Results indicated that infestation of $A$. catalaunalis on sesame plants commenced in the mid- June (15 day after sowing) then increased till the end of crop maturation (the third week of September). The incidence of sesame tender shoots during 2012 season began in mid-June in low numbers with the average population of 7 larvae/infested branch at the field conditions of $37.8^{\circ} \mathrm{C}$ and $86.7 \%$ R.H. and percentages of infested branches (15\%). The highest percentage of infestation (75\%) was observed during the last week of July at $\left(39.8^{\circ} \mathrm{C}\right.$ and $87.8 \%$ R.H $)$ and the average population/infested branch of (20.1 larvae). Thereafter, the population of larvae declined gradually (Table 1). The trend of the infestation in the second season was similar to that in the first season; being greatest $(70 \%)$ in last week of July accompanied by weather factors of $\left(37.5^{\circ} \mathrm{C}\right.$ and $89 \%$ R.H $)$ and the highest average number of larvae/infested branch was 18.5 larvae (Table 2).

\subsection{Seasonal incidence of $A$. catalunalis in leaves, flowers, and capsules}

The initial occurrence of $A$. catalaunalis larvae in vegetative stage was observed in mid-June with percentage of infested leaves of $17.5 \%$ and total larval population/40 infested leaves of 10 larvae accompanied with the field conditions of $37.8^{\circ} \mathrm{C}$ and $86.7 \%$ R.H (Figs. 1, 2 and 3). The percentages of infested leaves increased to reach a maximum of $72.5 \%$ with total larval population of 282 larvae/40 infested leaves coinciding with mean temperature of $42.8^{\circ} \mathrm{C}$ and relative humidity of $87.7 \%$ in mid-July. In flowering stage, the incidence of $A$. catalaunalis larvae began in $2^{\text {nd }}$ week of July at $37^{\circ} \mathrm{C}$ and $87.7 \%$ R.H, with the percentages of infested flowers of $20 \%$ and total population of 30 larvae/40 infested flowers. The percentages of infested flowers reached a maximum of $62.5 \%$ and population of larvae 118 larvae coinciding with field conditions of $39.8^{\circ} \mathrm{C}$ and $87.8 \%$ R.H the end of July. The initial damage to sesame seed capsules was observed in the second week of August at $38.4^{\circ} \mathrm{C}$ and $87.7 \%$ R.H with infestation percentage of $30 \%$ and total number of larvae of 24 larvae/infested capsules. The damage increased gradually to reach a maximum of $47.5 \%$ and its peak population of 56 larvae/infested capsules at the end of August $\left(38.2^{\circ} \mathrm{C}\right.$ and $88.8 \%$ R.H). In the second season and as depicted in Figs. 4, 5 and 6, the highest percentages of infested leaves, flowers and capsules were 70,55 and $45 \%$, respectively. The maximum total larval population in the infested leaves and flowers were 220 and 90 larvae, respectively at field conditions of $37.5^{\circ} \mathrm{C}$ and $89 \%$ R.H in the end of July. While, the maximum total larval population was 60 larvae/infested capsules at the last week of August coinciding with $38.4^{\circ} \mathrm{C}$ and $89 \%$ R.H. 
Table (1): Seasonal incidence of $A$. catalaunalis larvae/20 sesame tender shoots in 2012 season at Ismailia Governorate

\begin{tabular}{|c|c|c|c|c|c|c|c|}
\hline \multirow{2}{*}{$\begin{array}{l}\text { Sampling } \\
\text { date }\end{array}$} & \multirow{2}{*}{$\begin{array}{c}\text { Mean } \\
\text { Temp. } \square \\
\text { C }\end{array}$} & \multirow{2}{*}{$\begin{array}{c}\text { Mean } \\
\text { R.H.\% }\end{array}$} & \multirow{2}{*}{$\mathbf{N} *$} & \multicolumn{2}{|c|}{ Infested branches } & \multirow{2}{*}{$\begin{array}{l}\text { No. of larvae } \\
\text { /infested } \\
\text { branches }\end{array}$} & \multirow{2}{*}{$\begin{array}{c}\text { Mean no. of } \\
\text { larvae } \\
\text { /infested branch }\end{array}$} \\
\hline & & & & No. & $\%$ & & \\
\hline 14-Jun. & 37.8 & 86.7 & 20 & 3 & 15 & 21 & 7.0 \\
\hline 21-Jun. & 36.7 & 86 & 20 & 4 & 20 & 40 & 10.0 \\
\hline 28-Jun. & 37.2 & 86.2 & 20 & 7 & 35 & 90 & 12.8 \\
\hline 05-Jul. & 37.5 & 89 & 20 & 10 & 50 & 142 & 14.2 \\
\hline 12-Jul. & 37 & 87.7 & 20 & 12 & 60 & 182 & 15.1 \\
\hline 19-Jul. & 42.8 & 87.7 & 20 & 13 & 65 & 249 & 19.1 \\
\hline 26-Jul. & 39.8 & 87.8 & 20 & 15 & 75 & 302 & 20.1 \\
\hline 02-Aug. & 37 & 87.7 & 20 & 12 & 60 & 164 & 13.6 \\
\hline 09-Aug. & 38.4 & 87.7 & 20 & 11 & 55 & 147 & 13.3 \\
\hline 16-Aug. & 38.4 & 87.2 & 20 & 10 & 50 & 126 & 12.6 \\
\hline 23-Aug. & 38 & 88.7 & 20 & 8 & 40 & 88 & 11.0 \\
\hline 30-Aug. & 38.2 & 88.8 & 20 & 6 & 30 & 40 & 6.6 \\
\hline 06-Sep. & 36.7 & 88 & 20 & 0 & 0 & 0 & 0 \\
\hline 13-Sep. & 33.8 & 88.4 & 20 & 0 & 0 & 0 & 0 \\
\hline 20-Sep. & 36.4 & 86.5 & 20 & 0 & 0 & 0 & 0 \\
\hline
\end{tabular}

Table (2): Seasonal incidence of $A$. catalaunalis larvae/20 sesame tender shoots in 2013 season at Ismailia Governorate

\begin{tabular}{|c|c|c|c|c|c|c|c|}
\hline \multirow{2}{*}{$\begin{array}{l}\text { Sampling } \\
\text { date }\end{array}$} & \multirow{2}{*}{$\begin{array}{c}\text { Mean } \\
\text { Temp. } \square \\
\text { C }\end{array}$} & \multirow{2}{*}{$\begin{array}{c}\text { Mean } \\
\text { R.H.\% }\end{array}$} & \multirow{2}{*}{$\mathbf{N} *$} & \multicolumn{2}{|c|}{ Infested branches } & \multirow{2}{*}{$\begin{array}{c}\text { No. of larvae } \\
\text { /infested } \\
\text { branches }\end{array}$} & \multirow{2}{*}{$\begin{array}{c}\text { Mean no. of } \\
\text { larvae/infested } \\
\text { branch }\end{array}$} \\
\hline & & & & No. & $\%$ & & \\
\hline 10-Jun & 35.7 & 86.7 & 20 & 2 & 10 & 6 & 3 \\
\hline 17-Jun & 33.4 & 85.2 & 20 & 4 & 20 & 24 & 6 \\
\hline 24-Jun & 33.5 & 87 & 20 & 6 & 30 & 72 & 12 \\
\hline 01-Jul & 36 & 88.4 & 20 & 10 & 50 & 131 & 13.1 \\
\hline 08-Jul & 34.8 & 86.8 & 20 & 12 & 60 & 165 & 13.7 \\
\hline 15-Jul & 31.4 & 86.1 & 20 & 13 & 65 & 189 & 14.5 \\
\hline 22-Jul & 36.4 & 84.1 & 20 & 14 & 70 & 221 & 15.7 \\
\hline 29-Jul & 37.5 & 89 & 20 & 14 & 70 & 260 & 18.5 \\
\hline 05-Aug & 34.2 & 88 & 20 & 12 & 60 & 190 & 15.8 \\
\hline 12-Aug & 31.8 & 74.1 & 20 & 10 & 50 & 144 & 14.4 \\
\hline 19-Aug & 30.5 & 88.7 & 20 & 7 & 35 & 66 & 9.4 \\
\hline 26-Aug & 38.4 & 89 & 20 & 5 & 25 & 40 & 8 \\
\hline 02-Sep & 37.5 & 88.8 & 20 & 0 & 0 & 0 & 0 \\
\hline 09-Sep & 35.8 & 86.4 & 20 & 0 & 0 & 0 & 0 \\
\hline 16-Sep & 38 & 86.5 & 20 & 0 & 0 & 0 & 0 \\
\hline
\end{tabular}




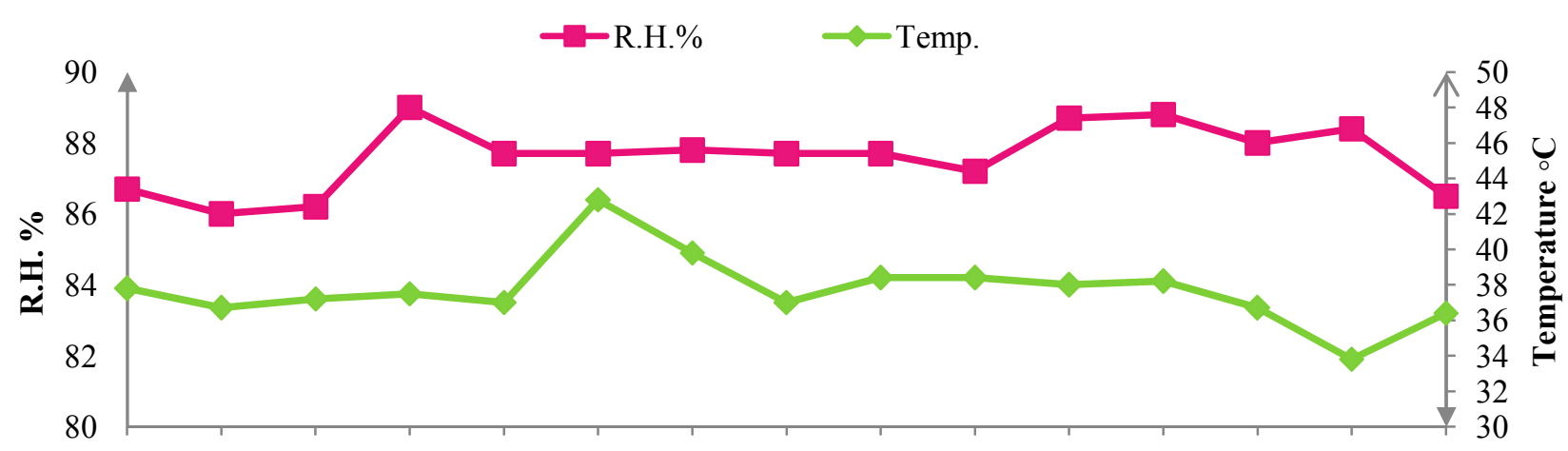

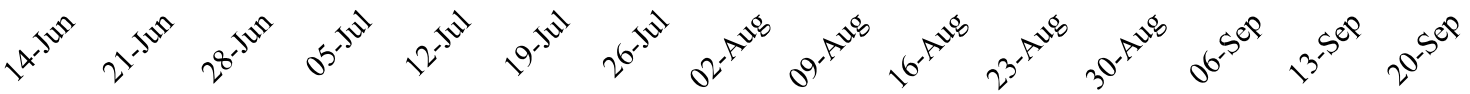

Sampling date, 2012

Fig. (1): Weekly means of temperature ${ }^{\circ} \mathrm{C}$ and relative humidity \% in 2012 season at Ismailia Governorate.

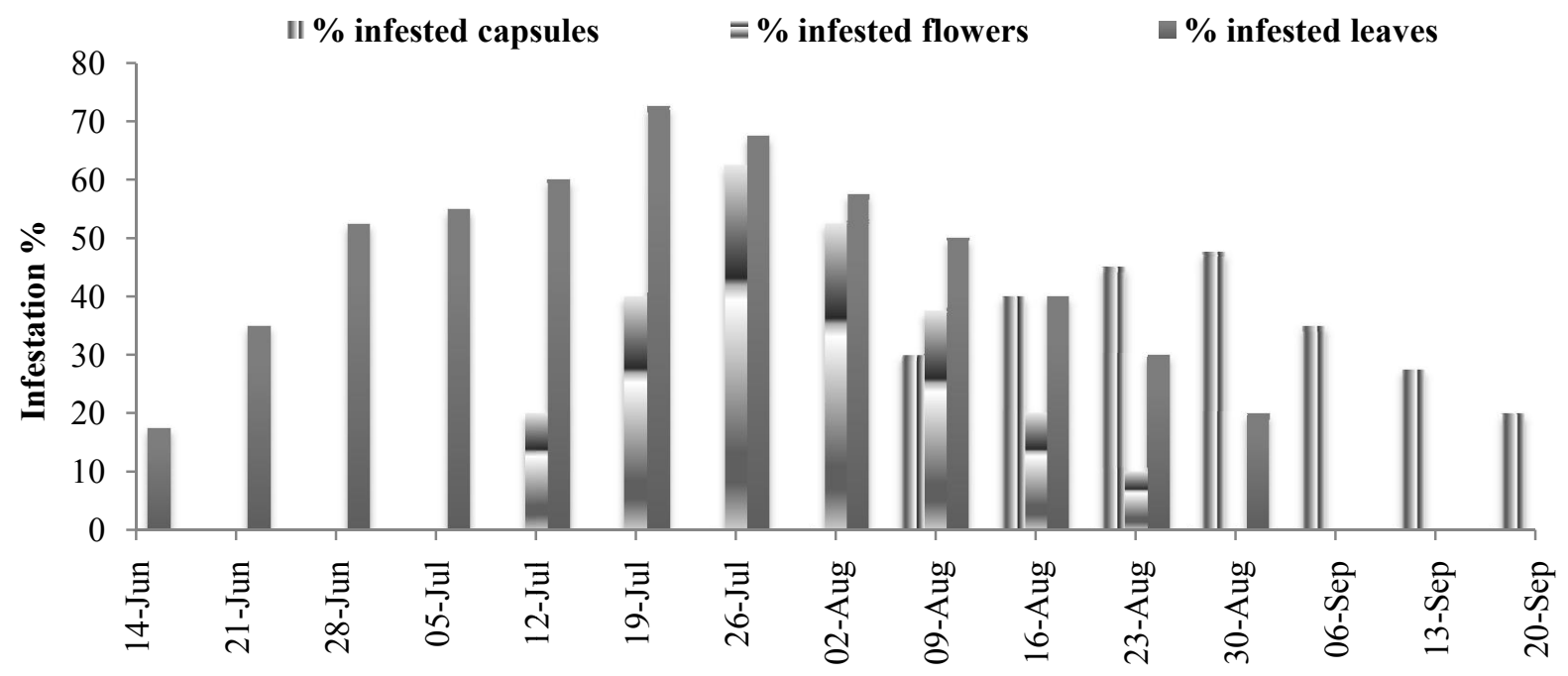

Sampling date, 2012

Fig. (2): Weekly percentages of infested sesame plants by $A$. catalaunalis larvae/40 leaves, flowers and capsules in sesame plants during 2012 season at Ismailia Governorate.

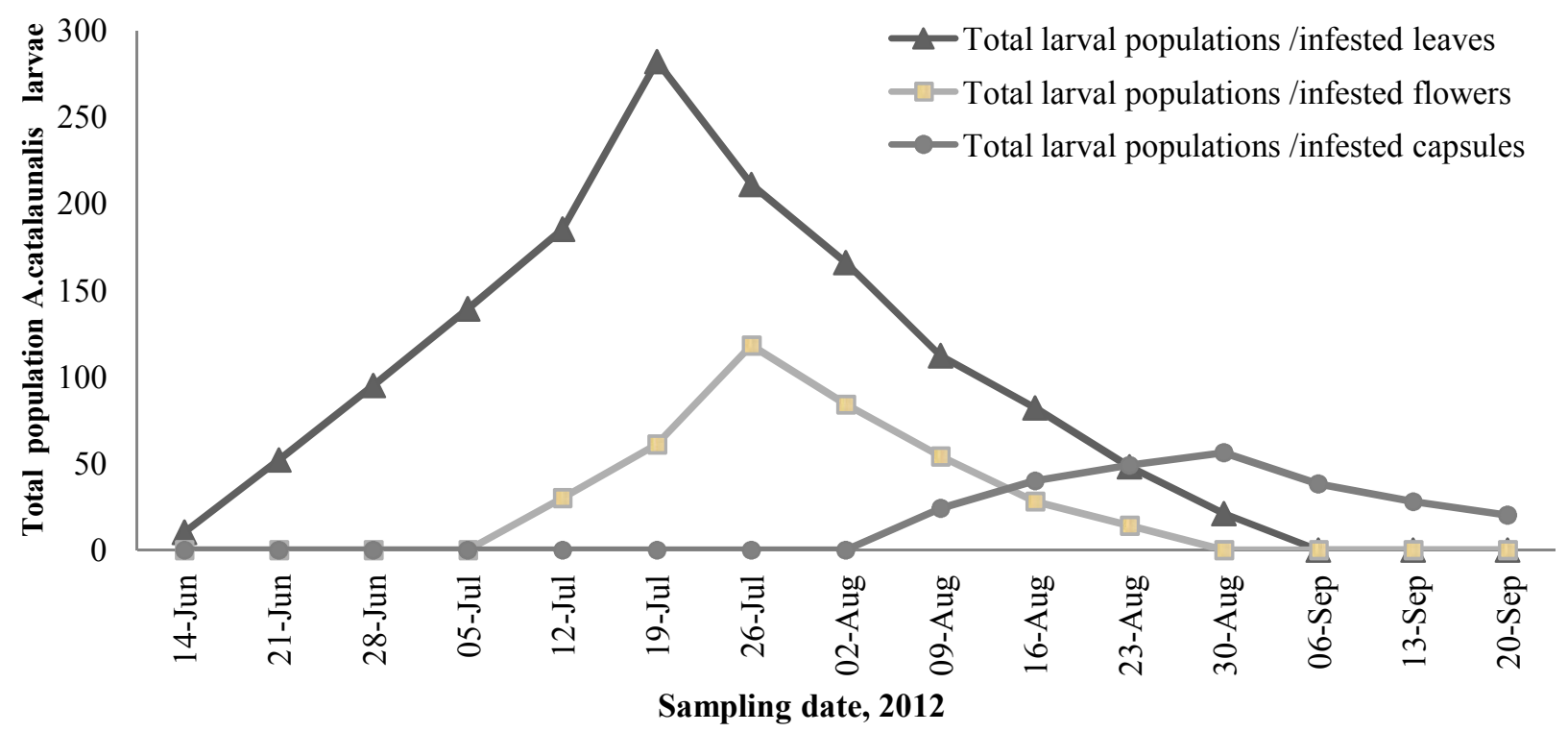

Fig. (3): Weekly total population of $A$. catalaunalis larvae/40 leaves, flowers and capsules in sesame plants during 2012 season at Ismailia Governorate 


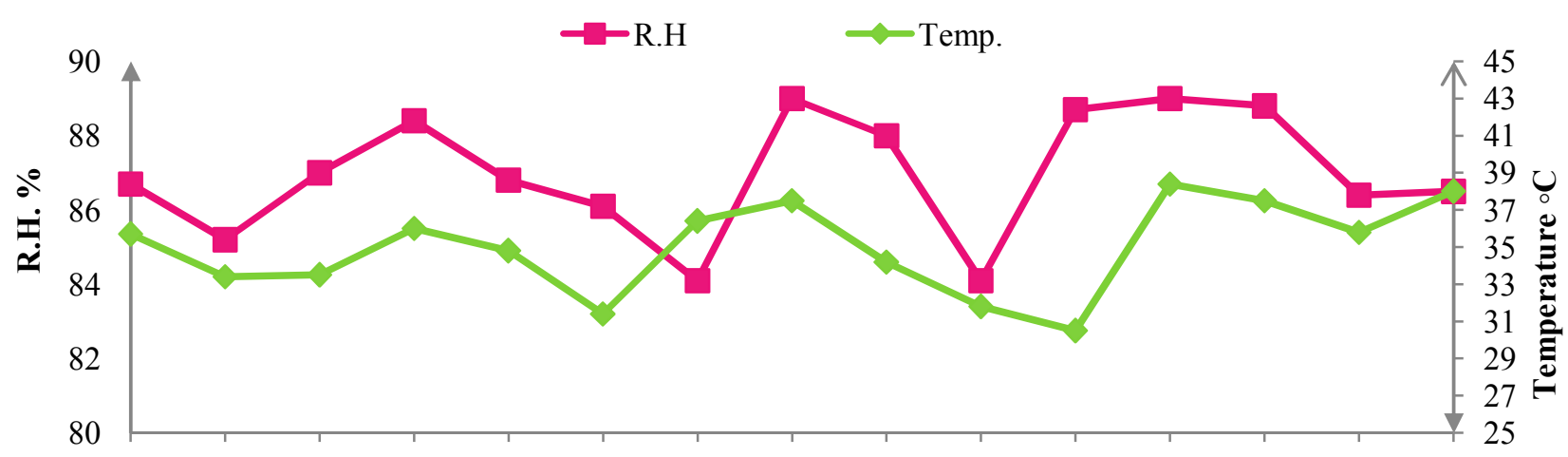

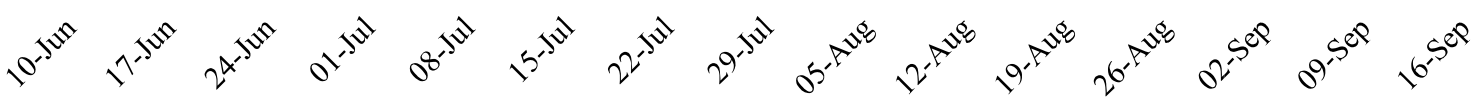

\section{Sampling date, 2013}

Fig. (4): Weekly means of temperature ${ }^{\square} \mathrm{C}$ and relative humidity \% in 2013 season at Ismailia Governorate

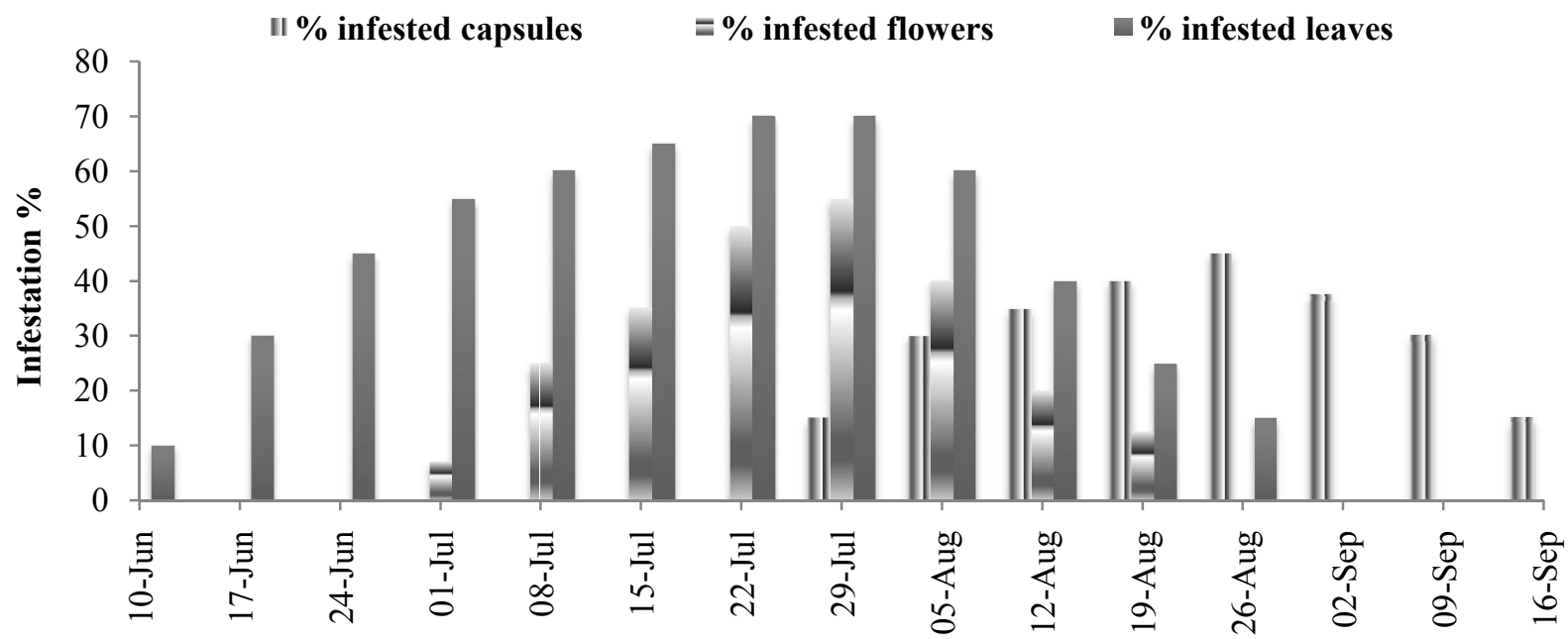

Sampling date, 2013

Fig. (5): Weekly percentages of infested sesame plants by $A$. catalunalis larvae/40 leaves, flowers and capsules in sesame plants during 2013 season at Ismailia Governorate

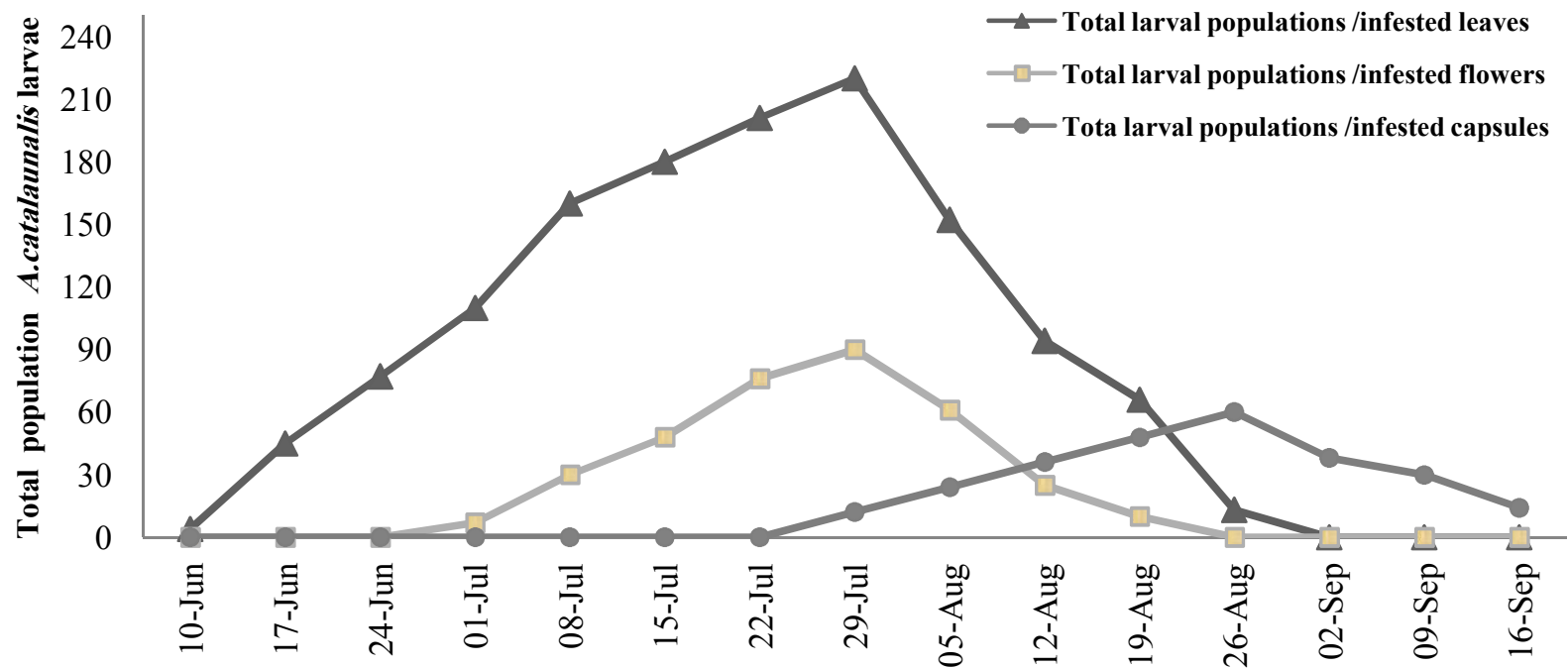

Sampling date, 2013

Fig. (6): Weekly total population of $A$. catalaunalis larvae/40 leaves, flowers and capsules in sesame plants during 2013 season at Ismailia Governorate 


\subsection{Effect of the climatic factors on seasonal incidence of $A$. catalaunalis}

In the first season, data in Table (3) showed that the weekly mean temperature had a significant positive effect with percentages of infested branch $(\mathrm{r}=0.66)$ and average larval population/infested branch $(0.70)$, while the mean relative humidity showed a non-significant positive effect $(r=0.21$ and 0.04$)$, respectively. In the second season, there was non-significant negative relationship between temperature and percentages of infested branch (-0.29) or average larval population/infested branch (-0.32). Also, the mean relative humidity had non- significant negative relationship between percentages of infested branch (0.11 ) or average larval population/infested branch ($0.06)$.

Table (3): Correlation coefficient between percentages of infested branches or number of larvae of A. catalaunalis /infested branch with weather factors during the two study seasons of 2012 and 2013

\begin{tabular}{|c|c|c|c|c|}
\hline \multirow{3}{*}{ Weather parameters } & \multicolumn{4}{|c|}{ Correlation of infested branches and aver. larval population in season 2012} \\
\hline & \multicolumn{2}{|c|}{ Infested branches\% } & \multicolumn{2}{|c|}{ Aver. larval population/infested branch } \\
\hline & $(\mathbf{r}) \pm \mathbf{S . E}$ & $\mathbf{P}$ & $(\mathbf{r}) \pm \mathbf{S . E}$ & $\mathbf{P}$ \\
\hline Mean Temp. $\left({ }^{\circ} \mathrm{C}\right)$ & $0.66 \pm 0.2$ & 0.006 & $0.70 \pm 0.19$ & 0.003 \\
\hline \multirow[t]{4}{*}{ Mean R.H (\%) } & $0.21 \pm 0.2$ & 0.441 & $0.04 \pm 0.2$ & 0.875 \\
\hline & \multicolumn{4}{|c|}{ Correlation of infested branches and aver. larval population in season 2013} \\
\hline & \multicolumn{2}{|c|}{ Infested branches\% } & \multicolumn{2}{|c|}{ Aver. larval population/infested branch } \\
\hline & $(\mathbf{r}) \pm \mathbf{S} . \mathbf{E}$ & $\mathbf{P}$ & (r) $\pm \mathbf{S . E}$ & $\mathbf{P}$ \\
\hline Mean Temp. $\left({ }^{\circ} \mathrm{C}\right)$ & $-0.29 \pm 0.2$ & 0.28 & $-0.32 \pm 0.2$ & 0.23 \\
\hline Mean R.H (\%) & $-0.11 \pm 0.2$ & 0.68 & $-0.06 \pm 0.2$ & 0.81 \\
\hline
\end{tabular}

$\mathrm{r}=$ Correlation coefficient

S.E. $=$ Standard errors

As shown in Table (4) in the first season, the incidence of $A$. catalaunalis in terms of percentage of infested plants (leaves and flowers) had a significant positive correlation with the mean temperature $(r=0.64$ and 0.55 , respectively). While on the opposite, correlation with infested capsules was non-significant negative correlation $(\mathrm{r}=-0.16)$. Percentage of infested plants had non-significant positive correlation with mean relative humidity in infested leaves, flowers and capsules $(\mathrm{r}=0.02,0.10$ and 0.42 , respectively).

The same trend of correlation was found between total larval population in infested plants (leaves and flowers) with mean temperature $(\mathrm{r}=0.69$ and 0.53 , respectively). On contrary, correlation between larval population in infested capsules was non- significant $(\mathrm{r}=$ -0.15 ). Mean relative humidity percentages showed no significant correlation with total larval population in infested leaves, flowers and capsules $(r=0.02,0.10$ and 0.42, respectively), (Table 4).

Meanwhile, in the second season (2013), percentage of infested plants had non-significant correlation with mean temperature; negative correlation in infested leaves and flowers $(r=-0.26$ and -0.12 respectively), but positive correlation was found in infested capsules $(r=0.02)$. Mean relative humidity had non-significant on percentage of infested plants; negative correlation $(-0.11,-0.16)$ in infested leaves and flowers while positive correlation $(r=0.37)$ in infested capsules.

The total larval population/infested plants had non-significant correlation with mean temperature; negative correlation in infested leaves and flowers $(\mathrm{r}=$ 0.21 and -0.01 , respectively) and positive correlation ( $\mathrm{r}$ $=0.06$ ) in infested capsules. Mean relative humidity had non-significant correlation with total larval population/infested plants; negative correlation with leaves, flowers ( $r=-0.12$ and -0.09 , respectively) and positive correlation $(\mathrm{r}=0.40)$ with infested sesame capsules.

\section{Parasitism rate in the field}

\subsection{Parasitism rates in host larvae fed on tender} shoots

The percentages of parasitism in A. catalaunalis larvae by $B$. hebetor varied in the two studying successive seasons and varied also in different sesame parts on which host larvae were fed upon (Tables 5 and 6 ). The occurrence and percentage parasitism relatively varied between two years; being higher in the second season. Meanwhile in the two seasons, the parasitoid was almost vanished up to the last week of June; being observed after that till end of August coinciding with the appearance of $A$. catalaunalis larvae on sesame vegetative stage. Percent of parasitism on larvae of $A$. catalaunalis by $B$. hebetor ranged from 11.7 to $28.3 \%$ during the first season and from 20 to $38.7 \%$ during the second one. The highest larval parasitism and parasitoids emergence percentages were 28.3 and $87.6 \%$, respectively at the field conditions of $37 \square \mathrm{C}$ and $87.7 \%$ R.H in the first week of August of the first season; whereas it were 38.7 and $88.6 \%$ coinciding with $34.2 \square \mathrm{C}$ and $88 \%$ R.H in the first week of August of the second season. 
Table (4): Correlation coefficient between percentages of infested sesame plants (leaves, flowers and capsules) by $A$. catalaunalis, with weather factors during the two study seasons of 2012 and 2013

Correlation of infested sesame plant in 2012 season

\begin{tabular}{|c|c|c|c|c|c|c|}
\hline \multirow[t]{2}{*}{ Weather parameters } & \multicolumn{2}{|c|}{ Infested leaves\% } & \multicolumn{2}{|c|}{ Infested flowers\% } & \multicolumn{2}{|c|}{ Infested capsules\% } \\
\hline & (r) $\pm \mathbf{S . E}$ & $\mathbf{P}$ & (r) \pm S.E & $\mathbf{P}$ & (r) \pm S.E & $\mathbf{P}$ \\
\hline Mean Temp. $\left({ }^{\circ} \mathrm{C}\right)$ & $0.64 \pm 0.2$ & 0.009 & $0.55 \pm 0.2$ & 0.03 & $-0.16 \pm 0.2$ & 0.55 \\
\hline \multirow[t]{3}{*}{ Mean R.H\% } & $0.02 \pm 0.2$ & 0.94 & $0.10 \pm 0.2$ & 0.71 & $0.42 \pm 0.2$ & 0.11 \\
\hline & \multicolumn{2}{|c|}{$\begin{array}{l}\text { Total larval population } \\
\text { /infested leaves }\end{array}$} & \multicolumn{2}{|c|}{$\begin{array}{l}\text { Total larval population } \\
\text { /infested flowers }\end{array}$} & \multicolumn{2}{|c|}{$\begin{array}{l}\text { Total larval population } \\
\text { /infested capsules }\end{array}$} \\
\hline & $(\mathbf{r}) \pm \mathbf{S} . \mathbf{E}$ & $\mathbf{P}$ & (r) $\pm \mathbf{S . E}$ & $\mathbf{P}$ & (r) $\pm \mathbf{S . E}$ & $\mathbf{P}$ \\
\hline Mean Temp. $\left({ }^{\circ} \mathrm{C}\right)$ & $0.69 \pm 0.1$ & 0.003 & $0.53 \pm 0.2$ & 0.04 & $-0.15 \pm 0.2$ & 0.57 \\
\hline Mean R.H (\%) & $0.02 \pm 0.2$ & 0.94 & $0.10 \pm 0.2$ & 0.71 & $0.42 \pm 0.2$ & 0.11 \\
\hline
\end{tabular}

Correlation of infested sesame plant in 2013 season

\begin{tabular}{|c|c|c|c|c|c|c|}
\hline & \multicolumn{2}{|c|}{ Infested leaves\% } & \multicolumn{2}{|c|}{ Infested flowers\% } & \multicolumn{2}{|c|}{ Infested capsules\% } \\
\hline & $(\mathbf{r}) \pm \mathbf{S . E}$ & $\mathbf{P}$ & $(\mathbf{r}) \pm \mathbf{S . E}$ & $\mathbf{P}$ & (r) \pm S.E & $\mathbf{P}$ \\
\hline Mean Temp. $\left({ }^{\circ} \mathrm{C}\right)$ & $-0.26 \pm 0.2$ & 0.33 & $-0.12 \pm 0.2$ & 0.66 & $0.02 \pm 0.2$ & 0.92 \\
\hline \multirow[t]{3}{*}{ Mean R.H\% } & $-0.11 \pm 0.2$ & 0.68 & $-0.16 \pm 0.2$ & 0.56 & $0.37 \pm 0.2$ & 0.17 \\
\hline & \multicolumn{2}{|c|}{$\begin{array}{l}\text { Total larval population } \\
\text { /infested leaves }\end{array}$} & \multicolumn{2}{|c|}{$\begin{array}{l}\text { Total larval population } \\
\text { /infested flowers }\end{array}$} & \multicolumn{2}{|c|}{$\begin{array}{l}\text { Total larval population/ } \\
\text { infested capsules }\end{array}$} \\
\hline & (r) $\pm \mathbf{S . E}$ & $\mathbf{P}$ & (r) $\pm \mathbf{S . E}$ & $\mathbf{P}$ & (r) \pm S.E & $\mathbf{P}$ \\
\hline Mean Temp. $\left({ }^{\circ} \mathrm{C}\right)$ & $-0.21 \pm 0.2$ & 0.44 & $-0.01 \pm 0.2$ & 0.96 & $0.06 \pm 0.2$ & 0.81 \\
\hline Mean R.H (\%) & $-0.12 \pm 0.2$ & 0.65 & $-0.09 \pm 0.2$ & 0.73 & $0.40 \pm 0.2$ & 0.13 \\
\hline
\end{tabular}

$\mathrm{r}=$ Correlation coefficient

S.E. $=$ Standard errors

Table (5): Rate of parasitism in A. catalaunalis larvae /20 Sesame tender shoots by B. hebetor during 2012 season at Ismailia Governorate

\begin{tabular}{|c|c|c|c|c|c|c|c|}
\hline $\begin{array}{l}\text { Sampling } \\
\text { date }\end{array}$ & $\begin{array}{c}\text { Mean } \\
\text { Temp. } \\
\square \mathbf{C}\end{array}$ & $\begin{array}{c}\text { Mean } \\
\text { R.H.\% }\end{array}$ & $\begin{array}{l}\text { Total no. of } \\
\text { collected } \\
\text { larvae }\end{array}$ & $\begin{array}{c}\text { No. of } \\
\text { parasitized } \\
\text { larvae }\end{array}$ & $\begin{array}{c}\text { Parasitism } \\
\%\end{array}$ & $\begin{array}{l}\text { Total no. of } \\
\text { parasitoids } \\
\text { cocoons* }\end{array}$ & $\begin{array}{c}\text { Parasitoid } \\
\text { emergence } \\
\%\end{array}$ \\
\hline 14-Jun. & 37.8 & 86.7 & 21 & 0 & 0 & 0 & 0 \\
\hline 21-Jun. & 36.7 & 86 & 40 & 0 & 0 & 0 & 0 \\
\hline 28-Jun. & 37.2 & 86.2 & 90 & 12 & 11.7 & 74 & 63.5 \\
\hline 05-Jul. & 37.5 & 89 & 142 & 28 & 16.4 & 140 & 71.4 \\
\hline 12-Jul. & 37 & 87.7 & 182 & 68 & 27.2 & 407 & 82.3 \\
\hline 19-Jul. & 42.8 & 87.7 & 249 & 86 & 25.6 & 408 & 80.8 \\
\hline 26-Jul. & 39.8 & 87.8 & 302 & 115 & 27.5 & 650 & 86.1 \\
\hline 02-Aug. & 37 & 87.7 & 164 & 65 & 28.3 & 485 & 87.6 \\
\hline 09-Aug. & 38.4 & 87.7 & 147 & 57 & 27.9 & 390 & 84.6 \\
\hline 16-Aug. & 38.4 & 87.2 & 126 & 48 & 27.5 & 300 & 84 \\
\hline 23-Aug. & 38 & 88.7 & 88 & 32 & 26.6 & 200 & 76 \\
\hline 30-Aug. & 38.2 & 88.8 & 40 & 8 & 16.6 & 40 & 62.2 \\
\hline 06-Sep. & 36.7 & 88 & 0 & 0 & 0 & 0 & 0 \\
\hline 13-Sep. & 33.8 & 88.4 & 0 & 0 & 0 & 0 & 0 \\
\hline 20-Sep. & 36.4 & 86.5 & 0 & 0 & 0 & 0 & 0 \\
\hline
\end{tabular}

*Summation of number of cocoons formed in the lab and in the field 
Table (6): Rate of parasitism in A. catalaunalis larvae /20 Sesame tender shoots by B. hebetor during 2013 season at Ismailia Governorate

\begin{tabular}{|c|c|c|c|c|c|c|c|}
\hline $\begin{array}{l}\text { Sampling } \\
\text { date }\end{array}$ & $\begin{array}{c}\text { Mean } \\
\text { Temp. } \\
\square \mathbf{C}\end{array}$ & $\begin{array}{c}\text { Mean } \\
\text { R.H \% }\end{array}$ & $\begin{array}{l}\text { Total no. of } \\
\text { collected } \\
\text { larvae }\end{array}$ & $\begin{array}{c}\text { No. of } \\
\text { parasitized } \\
\text { larvae }\end{array}$ & $\begin{array}{c}\text { Parasitism } \\
\%\end{array}$ & $\begin{array}{l}\text { Total no. of } \\
\text { parasitoids } \\
\text { cocoons* }\end{array}$ & $\begin{array}{c}\text { Parasitoid } \\
\text { emergence } \\
\%\end{array}$ \\
\hline 10-Jun. & 35.7 & 86.7 & 6 & 0 & 0 & 0 & 0 \\
\hline 17-Jun. & 33.4 & 85.2 & 24 & 0 & 0 & 0 & 0 \\
\hline 24-Jun. & 33.5 & 87 & 72 & 18 & 20 & 84 & 60.7 \\
\hline 01-Jul. & 36 & 88.4 & 131 & 45 & 25.5 & 140 & 71.4 \\
\hline 08-Jul. & 34.8 & 86.8 & 165 & 60 & 26.6 & 285 & 78.2 \\
\hline 15-Jul. & 31.4 & 86.1 & 189 & 95 & 33.4 & 408 & 80.8 \\
\hline 22-Jul. & 36.4 & 84.1 & 221 & 100 & 31.1 & 438 & 84.4 \\
\hline 29-Jul. & 37.5 & 89 & 260 & 140 & 35 & 480 & 86.4 \\
\hline 05-Aug. & 34.2 & 88 & 190 & 120 & 38.7 & 430 & 88.6 \\
\hline 12-Aug. & 31.8 & 74.1 & 144 & 68 & 32 & 300 & 84 \\
\hline 19-Aug. & 30.5 & 88.7 & 66 & 32 & 32.6 & 175 & 74.2 \\
\hline 26-Aug. & 38.4 & 89 & 40 & 20 & 33.3 & 40 & 62.5 \\
\hline 02-Sep. & 37.5 & 88.8 & 0 & 0 & 0 & 0 & 0 \\
\hline 09-Sep. & 35.8 & 86.4 & 0 & 0 & 0 & 0 & 0 \\
\hline 16-Sep. & 38 & 86.5 & 0 & 0 & 0 & 0 & 0 \\
\hline
\end{tabular}

*Summation of number of cocoons formed in the lab and in the field

\subsection{Parasitism rates in host larvae fed on leaves, flowers and capsules}

The parasitism rate of $A$. catalaunalis larvae fed on sesame leaves, flowers and capsules by $B$. hebetor during the first season was detected for the first time in the last week of June at $13.6 \%$ in infested leaves and reached its maximum $(32.5 \%)$ at the field conditions of $37 \square \mathrm{C}$ and $87.7 \%$ R.H in the first week of August. In infested flowers, the parasitism started in the third week in July (10.2\%) and reached a maximum parasitism of $26.3 \%$ at $37 \square \mathrm{C}$ and $87.7 \%$ R.H. In infested capsules, parasitism rate reached a maximum of $20 \%$ at field conditions of $38.2 \square \mathrm{C}$ and $88.8 \%$ at the end of August. The highest overall parasitism rate (all infested plant parts) was $30.5 \%$ in the first week of August at $37 \square \mathrm{C}$ and $87.7 \%$ R.H during the first season and $43.8 \%$ in the first week of August at $34.2 \square \mathrm{C}$ and $88 \%$ R.H during the second study season (Table 7 and 8).

\subsection{Effect of weather factors with larval population of $A$. catalaunalis on rate of parasitism}

In the first season, percentage of parasitism in $A$. catalaunalis larvae fed on sesame branches had a positive significant correlation with temperature $(\mathrm{r}=$ 0.57 ) and with total larval population of $A$. catalaunalis $(\mathrm{r}=0.82)$, while it had positively non- significant correlation $(\mathrm{r}=0.36)$ with relative humidity. Whereas, in the second season, parasitism rates had negatively non-significant correlation with temperature $(\mathrm{r}=-0.36)$ or relative humidity $(\mathrm{r}=-0.10)$ but it had highly positive significant correlation with total larval population of $A$. catalaunalis $(\mathrm{r}=0.86)$ (Table 9).

In the first season, temperature showed a significant positive effect $(\mathrm{r}=0.52)$ on parasitism percentages of $A$. catalaunalis larvae in infested leaves. While it showed a positive non-significant effect $(\mathrm{r}=$ 0.39 ) on parasitism percentages of $A$. catalaunalis larvae in infested flowers and a negative non-significant effect $(\mathrm{r}=-0.12)$ on parasitism percentages of $A$. catalaunalis larvae in infested capsules. Relative humidity showed non- significant correlation with parasitism percentages of $A$. catalaunalis larvae in infested leaves, flowers and capsules $(\mathrm{r}=0.34,0.11$ and 0.10 , respectively). Total larval population of $A$. catalaunalis showed highly significant correlation on parasitism percentages of $A$. catalaunalis larvae in infested leaves, flowers and capsules $(\mathrm{r}=0.80,0.83$ and 0.92 respectively, Table 9). In the second season, temperature showed non-significant negative effect on parasitism percentages in host larvae fed on leaves, flowers and capsules ( $\mathrm{r}=-0.17,-0.17$ and 0.03, respectively). Also, relative humidity showed nonsignificant negative correlation with parasitism percentages in leaves and flowers $(r=-0.11,-0.23$, respectively) and non-significant positive effect $(r=$ 0.13) in infested capsules. Meanwhile, parasitism percentages had highly significant positive effect with total number of $A$. catalaunalis larvae ( $\mathrm{r}=88,78$ and 97) on infested leaves, flowers and capsules respectively. 
Table (7): Parasitism percentages of $A$. catalaunalis larvae $/ 40$ sesame leaves, flowers and capsules by $B$. hebetor during 2012 season at Ismailia Governorate

\begin{tabular}{|c|c|c|c|c|c|c|c|c|c|c|c|c|c|}
\hline \multirow[b]{2}{*}{$\begin{array}{l}\text { Date } \\
2012\end{array}$} & \multirow[b]{2}{*}{$\mathbf{N}^{*}$} & \multicolumn{3}{|c|}{ Infested leaves } & \multicolumn{3}{|c|}{ Infested flowers } & \multicolumn{3}{|c|}{ Infested capsules } & \multicolumn{3}{|c|}{ Total } \\
\hline & & $\begin{array}{c}\text { Un- } \\
\text { parasitized } \\
\text { larvae }\end{array}$ & $\begin{array}{l}\text { Parasitized } \\
\text { larvae }\end{array}$ & $\begin{array}{c}\text { Parasitism } \\
\%\end{array}$ & $\begin{array}{c}\text { Un- } \\
\text { parasitized } \\
\text { larvae }\end{array}$ & $\begin{array}{l}\text { Parasitized } \\
\text { larvae }\end{array}$ & $\begin{array}{c}\text { Parasitism } \\
\%\end{array}$ & $\begin{array}{c}\text { Un- } \\
\text { parasitized } \\
\text { larvae }\end{array}$ & $\begin{array}{l}\text { Parasitized } \\
\text { larvae }\end{array}$ & $\begin{array}{c}\text { Parasitism } \\
\%\end{array}$ & $\begin{array}{c}\text { Un- } \\
\text { parasitized } \\
\text { larvae }\end{array}$ & $\begin{array}{l}\text { Parasitized } \\
\text { larvae }\end{array}$ & $\begin{array}{c}\text { Parasitism } \\
\% * *\end{array}$ \\
\hline 14-Jun. & 40 & 10 & 0 & 0 & 0 & 0 & 0 & 0 & 0 & 0 & 10 & 0 & 0 \\
\hline 21-Jun. & 40 & 52 & 0 & 0 & 0 & 0 & 0 & 0 & 0 & 0 & 52 & 0 & 0 \\
\hline 28-Jun. & 40 & 95 & 15 & 13.6 & 0 & 0 & 0 & 0 & 0 & 0 & 95 & 15 & 13.5 \\
\hline 05-Jul. & 40 & 139 & 35 & 20.1 & 0 & 0 & 0 & 0 & 0 & 0 & 139 & 35 & 20.1 \\
\hline 12-Jul. & 40 & 185 & 76 & 29.1 & 30 & 0 & 0 & 0 & 0 & 0 & 215 & 76 & 26.1 \\
\hline 19-Jul. & 40 & 282 & 88 & 23.7 & 61 & 7 & 10.2 & 0 & 0 & 0 & 343 & 95 & 21.6 \\
\hline 26-Jul. & 40 & 211 & 90 & 29.9 & 118 & 33 & 21.8 & 0 & 0 & 0 & 329 & 123 & 27.2 \\
\hline 02-Aug. & 40 & 166 & 80 & 32.5 & 84 & 30 & 26.3 & 0 & 0 & 0 & 250 & 110 & 30.5 \\
\hline 09-Aug. & 40 & 112 & 45 & 28.6 & 54 & 18 & 25 & 24 & 0 & 0 & 190 & 63 & 24.9 \\
\hline 16-Aug. & 40 & 82 & 24 & 23.5 & 28 & 7 & 20 & 40 & 3 & 6.9 & 150 & 34 & 18.4 \\
\hline 23-Aug. & 40 & 48 & 12 & 20 & 14 & 2 & 12.5 & 49 & 6 & 10.9 & 111 & 20 & 15.2 \\
\hline 30-Aug. & 40 & 21 & 4 & 16 & 0 & 0 & 0 & 56 & 14 & 20 & 77 & 18 & 18.9 \\
\hline 06-Sep. & 40 & 0 & 0 & 0 & 0 & 0 & 0 & 38 & 6 & 13.6 & 38 & 6 & 13.6 \\
\hline 13-Sep. & 40 & 0 & 0 & 0 & 0 & 0 & 0 & 28 & 2 & 6.6 & 28 & 2 & 6.6 \\
\hline 20-Sep. & 40 & 0 & 0 & 0 & 0 & 0 & 0 & 20 & 0 & 0 & 20 & 0 & 0 \\
\hline
\end{tabular}

$\mathrm{N}^{*}$ indicates total number of inspected plant part each sampling interval

**overall percentage of parasitism in all inspected plant parts 
Table (8): Parasitism percentages of $A$. catalaunalis larvae/40 Sesame leaves, flowers and capsules by $B$. hebetor during 2013 season at Ismailia Governorate.

\begin{tabular}{|c|c|c|c|c|c|c|c|c|c|c|c|c|c|}
\hline \multirow{2}{*}{$\begin{array}{l}\text { Date } \\
2012\end{array}$} & \multirow[b]{2}{*}{$\mathbf{N *}$} & \multicolumn{3}{|c|}{ Infested leaves } & \multicolumn{3}{|c|}{ Infested flowers } & \multicolumn{3}{|c|}{ Infested capsules } & \multicolumn{3}{|c|}{$\begin{array}{c}\text { Total infested on different parts of } \\
\text { plant }\end{array}$} \\
\hline & & $\begin{array}{c}\text { Un- } \\
\text { parasitized } \\
\text { larvae }\end{array}$ & $\begin{array}{l}\text { Parasitized } \\
\text { larvae }\end{array}$ & $\begin{array}{c}\text { Parasitism } \\
\quad \%\end{array}$ & $\begin{array}{c}\text { Un- } \\
\text { parasitized } \\
\text { larvae }\end{array}$ & $\begin{array}{l}\text { Parasitized } \\
\text { larvae }\end{array}$ & $\begin{array}{c}\text { Parasitism } \\
\quad \%\end{array}$ & $\begin{array}{c}\text { Un- } \\
\text { parasitized } \\
\text { larvae }\end{array}$ & $\begin{array}{l}\text { Parasitized } \\
\text { larvae }\end{array}$ & $\begin{array}{c}\text { Parasitism } \\
\quad \%\end{array}$ & $\begin{array}{c}\text { Un- } \\
\text { parasitized } \\
\text { larvae } \\
\end{array}$ & $\begin{array}{l}\text { Parasitized } \\
\text { larvae }\end{array}$ & $\begin{array}{l}\text { Parasitism } \\
\% * *\end{array}$ \\
\hline 10-Jun. & 40 & 4 & 0 & 0 & 0 & 0 & 0 & 0 & 0 & 0 & 4 & 0 & 0 \\
\hline 17-Jun. & 40 & 45 & 0 & 0 & 0 & 0 & 0 & 0 & 0 & 0 & 45 & 0 & 0 \\
\hline 24-Jun. & 40 & 77 & 20 & 20.6 & 0 & 0 & 0 & 0 & 0 & 0 & 77 & 20 & 20.6 \\
\hline 01-Jul. & 40 & 110 & 38 & 25.6 & 7 & 0 & 0 & 0 & 0 & 0 & 117 & 38 & 24.5 \\
\hline 08-Jul. & 40 & 160 & 80 & 33.3 & 30 & 0 & 0 & 0 & 0 & 0 & 190 & 80 & 29.6 \\
\hline 15-Jul. & 40 & 180 & 50 & 21.7 & 48 & 8 & 14.2 & 0 & 0 & 0 & 228 & 58 & 20.2 \\
\hline 22-Jul. & 40 & 201 & 100 & 33.2 & 76 & 34 & 30.9 & 0 & 0 & 0 & 277 & 134 & 32.6 \\
\hline 29-Jul. & 40 & 220 & 158 & 41.7 & 90 & 48 & 35.8 & 12 & 0 & 0 & 322 & 206 & 39 \\
\hline 05-Aug. & 40 & 152 & 85 & 35.8 & 61 & 20 & 24.6 & 24 & 2 & 7.6 & 137 & 107 & 43.8 \\
\hline 12-Aug. & 40 & 94 & 40 & 29.8 & 25 & 7 & 21.8 & 36 & 7 & 16.2 & 155 & 54 & 25.8 \\
\hline 19-Aug. & 40 & 66 & 17 & 20.4 & 10 & 2 & 16.6 & 48 & 9 & 15.7 & 124 & 28 & 18.4 \\
\hline 26-Aug. & 40 & 13 & 3 & 18.7 & 0 & 0 & 0 & 60 & 6 & 21 & 73 & 9 & 10.9 \\
\hline 02-Sep. & 40 & 0 & 0 & 0 & 0 & 0 & 0 & 38 & 7 & 15.5 & 38 & 7 & 15.5 \\
\hline 09-Sep. & 40 & 0 & 0 & 0 & 0 & 0 & 0 & 30 & 3 & 9 & 30 & 3 & 9 \\
\hline 16-Sep. & 40 & 0 & 0 & 0 & 0 & 0 & 0 & 14 & 0 & 0 & 14 & 0 & 0 \\
\hline
\end{tabular}

$\mathrm{N}^{*}$ indicates total number of inspected plant part each sampling interval

$* *$ overall percentage of parasitism in all inspected plant parts 
Table (9): Correlation coefficient between climatic factors and total larval population of $A$. catalaunalis with parasitism rates by $B$. hebetor in infested sesame branches, leaves, flowers and capsules in the two study seasons of 2012 and 2013

\begin{tabular}{|c|c|c|c|c|c|c|}
\hline \multirow[t]{3}{*}{ Parameters } & \multicolumn{6}{|c|}{$\begin{array}{l}\text { Correlation of parasitism percentages of } A \text {. catalaunalis larvae/branches in the } \\
\text { seasons of } 2012 \text { and } 2013\end{array}$} \\
\hline & \multicolumn{3}{|c|}{ Parasitism \%2012 } & \multicolumn{3}{|c|}{ Parasitism \%2013 } \\
\hline & \multicolumn{2}{|c|}{ (r) $\pm \mathbf{S . E}$} & $\mathbf{P}$ & \multicolumn{2}{|c|}{$(\mathbf{r}) \pm \mathbf{S . E}$} & $\mathbf{P}$ \\
\hline Mean Temp. $\left({ }^{\circ} \mathrm{C}\right)$ & \multicolumn{2}{|c|}{$0.57 \pm 0.2$} & 0.02 & \multicolumn{2}{|c|}{$-0.36 \pm 0.2$} & 0.18 \\
\hline Mean R.H (\%) & \multicolumn{2}{|c|}{$0.36 \pm 0.2$} & 0.18 & \multicolumn{2}{|c|}{$-0.10 \pm 0.2$} & 0.71 \\
\hline Total larval population & \multicolumn{2}{|c|}{$0.82 \pm 0.1$} & 0.0002 & \multicolumn{2}{|c|}{$0.86 \pm 0.1$} & 0.0000 \\
\hline \multirow{3}{*}{ Parameters } & \multicolumn{6}{|c|}{$\begin{array}{l}\text { Correlation of parasitism percentages of } A \text {. catalaunalis larvae in the season of } \\
2012\end{array}$} \\
\hline & \multicolumn{2}{|c|}{$\begin{array}{l}\text { \% parasitism in } \\
\text { infested leaves }\end{array}$} & \multicolumn{2}{|c|}{$\begin{array}{l}\text { \% parasitism in infested } \\
\text { flowers }\end{array}$} & \multicolumn{2}{|c|}{$\begin{array}{l}\text { \% parasitism in } \\
\text { infested capsules }\end{array}$} \\
\hline & (r) \pm S.E & $\mathbf{P}$ & (r) $\pm \mathbf{S . E}$ & $\mathbf{P}$ & $(\mathbf{r}) \pm \mathbf{S . E}$ & $\mathbf{P}$ \\
\hline Mean Temp. $\left({ }^{\circ} \mathrm{C}\right)$ & $0.52 \pm 0.2$ & 0.04 & $0.39 \pm 0.2$ & 0.14 & $-0.12 \pm 0.2$ & 0.64 \\
\hline Mean R.H (\%) & $0.34 \pm 0.2$ & 0.20 & $0.11 \pm 0.2$ & 0.69 & $0.10 \pm 0.2$ & 0.44 \\
\hline Total larval population & $0.80 \pm 0.1$ & 0.0003 & $0.83 \pm 0.1$ & 0.0001 & $0.92 \pm 0.1$ & 0.000 \\
\hline \multirow{3}{*}{ Parameters } & \multicolumn{6}{|c|}{$\begin{array}{l}\text { Correlation of parasitism percentages of } \text { A. catalaunalis larvae in the season of } \\
2013\end{array}$} \\
\hline & \multicolumn{2}{|c|}{$\begin{array}{l}\% \text { parasitism in infested } \\
\text { leaves }\end{array}$} & \multicolumn{2}{|c|}{$\begin{array}{l}\% \text { parasitism in infested } \\
\text { flowers }\end{array}$} & \multicolumn{2}{|c|}{$\begin{array}{l}\text { \% parasitism in } \\
\text { infested capsules }\end{array}$} \\
\hline & $(\mathbf{r}) \pm \mathbf{S . E}$ & $\mathbf{P}$ & (r) \pm S.E & $\mathbf{P}$ & (r) \pm S.E & $\mathbf{P}$ \\
\hline Mean Temp. $\left({ }^{\circ} \mathrm{C}\right)$ & $-0.17 \pm 0.2$ & 0.54 & $-0.17 \pm 0.2$ & 0.52 & $-0.03 \pm 0.2$ & 0.88 \\
\hline Mean R.H (\%) & $-0.11 \pm 0.2$ & 0.68 & $-0.23 \pm 0.2$ & 0.39 & $-0.13 \pm 0.2$ & 0.64 \\
\hline Total larval population & $0.88 \pm 0.1$ & 0.0000 & $0.78 \pm 0.1$ & 0.0005 & $0.97 \pm 0.06$ & 0.0000 \\
\hline
\end{tabular}

\section{DISCUSSION}

In this study, $A$. catalaunalis is considered a major pest for sesame plants. Results indicated that initial occurrence of $A$. catalaunalis larvae was observed in mid-June then increased gradually till capsule maturation $\left(2^{\text {nd }}\right.$ or $3^{\text {rd }}$ week of September). Kumar and Goel (1994b), Kumar et al. (2012) reported that $A$. catalaunalis as one of the key pests of sesame in India and it was active from seedling to harvesting stage of the crop. The population of $A$. catalaunalis larvae was higher in vegetative parts than flowering parts or capsules. These results agree with those reported earlier in several studies. For example, Mahadevan and Mahanasudaram (1986) reported that A. catalaunalis infested flowers more than pods and it might cause up to $53 \%$ seed loss. However, the present findings disagree with Muzaffar et al. (2002) who mentioned that the incidence of $A$. catalaunalis and its damage to sesame capsules was significantly greater than vegetative and flowering damage.

Temperature played an important role in influencing the period of development of $A$. catalaunalis. The effect of the tested weather factors on seasonal incidence of $A$. catalaunalis in the two studying successive seasons, determine the preferable time for the insect activity and the proper time for its control. Data showed that the mean temperature had a significant positive effect on percentages of infested branches, leaves and flowers or pest incidence (larval population/infested vegetative and flowers) except to capsules when temperature ranged between (33.8 $42.8^{\circ} \mathrm{C}$ ) during the first season. The mean relative humidity between (86 - $89 \%$ R.H) was insignificant negative relationship between percentages of infestation and larval population. These findings are in harmony with those reported by Vishnupriya et al. (2003) who mentioned that maximum and minimum temperature were positively correlated with pest incidence whereas the relative humidity showed a non-significant positive correlation with the pest incidence. Whereas, in the second season, when the temperature ranged between $\left(31.4-37.5^{\circ} \mathrm{C}\right)$ it showed non-significant negative relationship between temperature and percentages of infestation or larval population of infested vegetative and flowering except to capsules. The mean relative humidity between $(84.1-89 \%)$ showed non- significant negative relationship with percentages of infestation or pest incidence during the two seasons. Kumar and Goel (1994b) reported that the average weekly temperature $\left(28.85-29.75^{\circ} \mathrm{C}\right)$ and relative humidity (71.21 - 72.21\%) were the most favorable environmental conditions for rapid population increase of $A$. catalaunalis. There was a strong negative correlation between larval population and maximum temperature and R.H. (Kumar et al., 2012). In cases of severe infestation, yield is affected considerably (Singh et al., 1985; Singh et al., 1986; Mahadevan and Mohanasoudaran, 1986; Chaudhry et al., 1989; Baskaran and Thangavelu, 1991).

The occurrence and percentage of parasitism by $B$. hebetor varied during the two study successive seasons; being relatively higher in the second season. $B$. hebetor is known as a parasitoid of pyralid moth larvae infesting stored grains and field crops (Gupta and Sharma, 2004; 
Shojaei et al., 2006). However, little information is available on the seasonal occurrence of $A$. Catalaunalis or its parasitoids. Jakhmola (1983) recorded B. hebetor from $A$. catalaunalis during the field studies. Seasonal occurrence and field parasitism of $B$. hebetor indicated that during the two seasons, the parasitoid was not observed up to the last week of June. Rate of parasitism by $B$. hebetor varied among infested plant parts. Rates of parasitism were higher in the second season; being 41.7 and $38.7 \%$ in infested leaves and branches, and 35.8 and $21 \%$ in infested flowers and capsules. The higher rates of parasitism in host larvae fed on plant leaves are mainly due to two reasons. First the feeding habits in which larvae are more exposed and vulnerable to parasitoid adults than those concealed inside flowers and sesame capsules. Second, sesame flowers and capsules are available for short period of time as compared to sesame leaves.

It could be concluded that $A$. catalaunalis is a key pest for sesame crop in Egypt. Its population was strongly affected by the ambient temperature but not affected by relative humidity. Also, larval population varied in plant parts on which they were fed on. $B$. hebetor showed great potential as ecto-larval parasitoid for $A$. catalaunalis in Egypt. $B$. hebetor kill larvae of $A$. catalaunalis by parasitization and by host feeding that would undoubtedly, lead to suppress the natural population of this pest under field conditions.

\section{REFERENCES}

Abbas, O., A. Bath and R. Eglal (1989). Sesame and sunflower sub networks. Proceedings of the Joint second workshop held in Cairo, Egypt, 9-12 September 1989.

Ahirwar, R. M., M. P. Gupta and B. Smita (2010). BioEcology of leaf roller and capsule borer, Antigastra catalaunalis Duponchel. Advances Bioresearch, 1(2): $90-104$

Ahmed, K. Z. (2007). Comparison of research on sesame (Sesamum indicum) and nakati (Solanum aethiopicum) at Makerere University. Proceeding of the $8^{\text {th }}$ African Crop Science Society Conference, Vol. 8. pp. 2063-2069. El-Minia, Egypt.

Baskaran, R. and S. Thangavelu (1991). Biological control of Antigastra catalaunalis and its parasitoid Trathala Flavo-orbitalis Cameron. Sesame and Safflower Newsletter, 6: 8-10.

Chaudhary, R., S. Rai and K. M. Singh (1987). Economic injury level of sesame leaf webber, Antigastra catalaunalis (Dup.) in Delhi. Indian Journal of Plant Protection, 15(2): 136-141.

Chaudhry, A. H., B. R. Oad and K. Mehring (1989). Highlights of improvement research on oilseed crops in Sindh. Oilseed section, Agri. Research Institute. Tandojam, pp: 15-17.

Desai, V. S., D. D. Nagwekar, P. D. Patil and A. L. Narangalkar (2007). Field evaluation of a larval parasite Bracon hebetor Say against coconut black headed caterpillar. Journal Plant at Crops, 35: 188-189.
El-Basha, N. A. (2015). Developmental and reproductive biology of the ecto-larval parasitoid Bracon hebetor Say (Hymenoptera: Braconidae) on sesame capsule borer, Antigastra catalaunalis (Duponchel) (Lepidoptera-Pyralidae). Egyptian Academic Journal of Biological Sciences (A. Entomology), 8(3): 69-78.

Fagundes, G. G., H. Mohamed and D. R. Solis (2005). Biological responses of Anagasta kuehniella and its parasitoid, Bracon hebetor to microwaves radiation $(2450 \mathrm{MHz})$. Review Agriculture Piracicaba, 80: 12-34.

Gupta, S. and H. B. Sharma (2004). Bracon hebetor Say is the natural enemy of Ephestia calidella (Guen.) a pest of stored dry fruits. Uttar Pradesh journal of Zoology, 24: 223-226.

Iwo, G. A, A. A. Idowu and A. A. Ochigbo (2002). Sesame genotypes for field stability and selection in Nigeria, Nigerian Agricultural Journal, 33: 7682.

Jakhmola, S. S. (1983). Natural enemies of capsule borer, A. catalaunalis. Journal Bulletin of Entomology, 24(2): 147-148.

Kumar S. and SC. Goel (1994a). Studies of the life history of a pyralid, Antigastra catalaunalis (Duponchel) in Western Uttar Pradesh. Bulletin of Entomology, New Delhi, 35(1-2): 123-128.

Kumar S. and S. C. Goel (1994b). Population dynamics of a pyralid Antigastra catalaunalis Dup. on sesame in relation to abiotic factors. Journal of Entomological Research, 18(1): 61-64

Kumar, R., S. Ali and R. K. Dhoray (2012). Incidence of Antigastra catalaunalis, Dup. in Different Varieties of sesame. Molecular Entomology, 3(1): 15-17.

Kapadia, M. N. (1996). Estimation of losses due to borers in oilseed crops. Journal of oilseeds research, 13(1): 139-140.

Kyoung, D. J., D. H. Ha, S. K. Nho, K. S. Song and K. Y. Lee (2008). Up regulation of heat stock protein genes by envenomation of ectoparasitoid Bracon hebetor in larval host of Indian meal moth, Plodia interpunctella. Journal of Invertebrate Pathology, 97: 306-309.

Mahadevan, N. R. and M. Mahanasudaram (1986). Field evaluation of insecticides for their efficacy in control of sesame leaf webber, Oil crop newsletter, 3: 47-48.

Muzaffar, A. T., D. K. Rab, A. R. Maqsood and A. N. Imtiaz (2002). Insect pests associated with sesame at Tando Jam. Pakistan journal of applied sciences, 2(7): 723-726.

Narayanan, U. and L. Nadarajan (2005). Evidence for a male- produced sex pheromone in sesame leaf webber, Antigastra catalaunalis Duponchel (Pyralidae: Lepidoptera). Journal Current Sciences, 88(4): 631-634.

Seegeler, C. J. (1983). Oil plants in Ethiopia, their taxonomy and agricultural significance. Centre for Agricultural publishing and documentation, Wageningen. 376 pp. ref. p. 120-121. 
Selvanarayanan, V. and B. Baskaran (1996). Varietal response of sesame to the shoot webber and capsule borer Antigastra catalaunalis Duponchel (Lepidoptera: Pyraustidae). International Journal Pest Management, 42(4): 335-336.

Shojaei, S., M. Safaralizadeh and N. Shayesteh (2006). Effect of temperature on the functional response of Habrobracon hebetor Say to various densities of the host, Plodia interpunctella (Hubner). Pakistan Journal of Entomology, 28: 51-55.

Singh, H. (1983). Biology and Assessment of losses caused by leaf roller and pod borer Antigastra catalaunalis to sesame. M.Sc., Thesis. Haryana Agriculture University, Hissar, India.

Singh, H., V. kalra and H. Rohilla (1985). Assessment of losses in sesame caused by shoot webber and capsule borer in Haryana, India. Oil crops Newsletter, 2: 23-25.
Singh, H., S. Yadve and H. Rohilla (1986). Population dynamics of sesame shoot webber and pod borer Antigastra catalaunalis Dup. under field condition. Sesame and Safflower Newsletter, 2: 15.

Suliman, E. H., H. H. Nabil and O. Alawia (2004). Evaluation of some insecticides for the control of sesame webworm, Antigastra catalaunalis (Dup.) Proceedings of the Second National Pest Management Conference in the Sudan, 6-9 December, 2004. Faculty of Agricultural Sciences, University of Gezira, Sudan.

Vishnupriya, R., A. A. Bright, V. Paramasivam, V. Manoharan and J. Fernandez-Martinez (2003). Seasonal occurrence of sesame shoots webber (Antigastra catalaunalis Dup.). Sesame and Safflower Newsletter, 18: 70-71.

\section{الظهور الموسمي لحفار قرون السمسم Antigastra catalaunalis (Duponchel) التطقل لطفيل اليرقات الخارجي في Bracon hebetor Say علي نباتات السمسم في محافظة الإسماعيلية

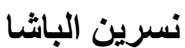 \\ قسم بحوث المكافحة البيولوجية، معهد بحوث وقاية النباتات، مركز البحوث الزراعية، الجيزة، مصر
}

Antigastra catalaunalis (Duponchel) تم إجراء تجارب حقلية لداسة الظهور الموسمي لحفار قرون السمسم) Bracon hebetor Say (Hymenoptera: Braconidae) (Lepidoptera: Pyralidae)

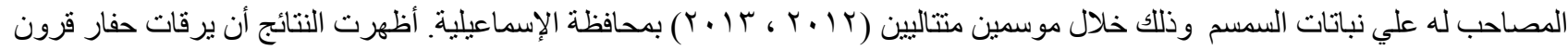

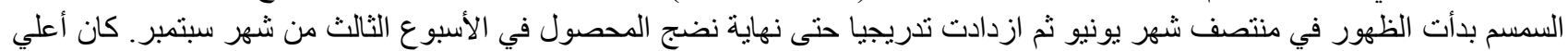

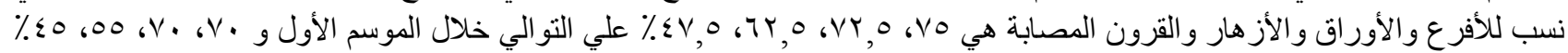

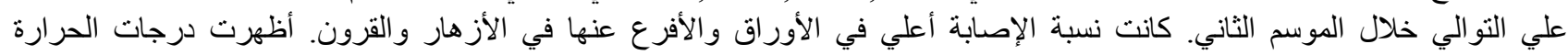

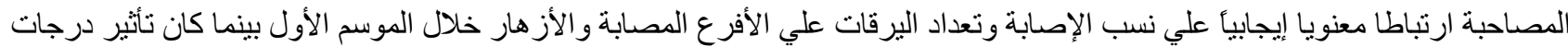

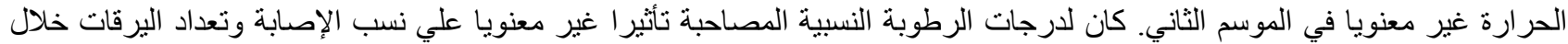

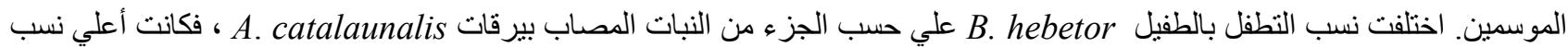

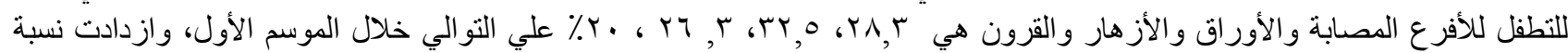

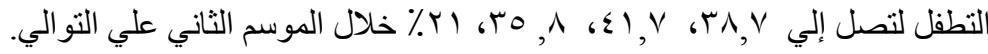

